\title{
PENERAPAN MODEL PEMBELAJARAN KOOPERATIF TIPE THINK PAIR SHARE (TPS) DALAM MENINGKATKAN AKTIVITAS DAN HASIL BELAJAR IPS TERPADU SISWA KELAS IX-A SMP NEGERI 1 TAMBANGAN
}

\author{
Pargugunan \\ Guru SMP Negeri 1 Tambangan \\ Surel : pargugunan@gmail.com
}

\begin{abstract}
Abstrak
Model pembelajaran kooperatif tipe Think Pair Share (TPS) dapat meningkatkan keaktifan dan prestasi belajar siswa pada mata pelajaran IPS. Data aktivitas siswa menurut pengamatan pengamat pada Siklus I diketahui : membaca/menulis (23.75\%), mengerjakan $(15.00 \%)$, bertanya pada teman $(20.63 \%)$, bertanya pada guru $(21.25 \%)$, dan yang tidak relevan dengan KBM (19.38\%). Sedangkan Data aktivitas siswa yang diperoleh pengamat pada Siklus II antara lain membaca/menulis (28.13\%), mengerjakan $(40.00 \%)$, bertanya pada teman $(20.00 \%)$, bertanya pada guru $(8.13 \%)$, dan yang tidak relevan dengan KBM (3.75\%). Setelah dilakukan pembelajaran dengan menerapkan model pembelajaran kooperatif tipe Think-pair-share hasil belajar siswa mengalami peningkatan pada akhir Siklus I dengan rata-rata 74.00 dan akhir Siklus II dengan ratarata 86.50 dan ketuntasan klasikal $60 \%$ pada Siklus I menjadi $90 \%$ pada Siklus II sehingga mengalami peningkatan $30 \%$.
\end{abstract}

Kata kunci : Model, Hasil belajar, Think-pair-share.

\section{PENDAHULUAN}

Pendidikan merupakan salah satu sektor penting yang harus ditangani oleh suatu bangsa, karena pada hakekatnya pendidikan merupakan proses untuk membangun manusia dalam mengembangkan dirinya agar dapat menghadapi segala perubahan dan permasalahan yang terjadi di lingkungan sekitarnya. Pendidikan adalah usaha sadar dan terencana untuk mewujudkan pembelajaran, suasana belajar dan proses belajar membantu peserta didik secara aktif mengembangkan potensi dirinya sendiri. Penyelenggaraan Pendidikan merupakan tanggung jawab bersama antara pemerintah, masyarakat dan keluarga. Masing-masing memiliki peran yang sangat besar dalam rangka mewujudkan tujuan Pendidikan. Keberhasilan penyelenggaraan Pendidikan merupakan keberhasilan bersama. Tidak bisa salah satu pihak menyatakan dirinya sebagai yang paling berhasil dalam penyelenggaraan Pendidikan.

Guru merupakan tenaga pendidik yang secara langsung terlibat dalam proses belajar mengajar, maka guru sebagai pendidik memegang peranan penting dalam meningkatkan kualitas sumberdaya manusia, guru sebagai 
ujung tombak peningkatan mutu pendidikan, pengajar maupun pendidik sehingga guru dituntut untuk memiliki berbagai kompetensi yang diperlukan agar materi yang disampaikan dapat diterima dengan baik. Guru menggunakan strategi belajar yang tidak mengharuskan siswa menghafal fakta- fakta tetapi sebuah strategi yang mendorong siswa membangun pengetahuan di benak mereka sendiri. Model pembelajaran yang digunakan guru sangat berpengaruh dalam menciptakan situasi belajar yang benar-benar menyenangkan dan mendukung kelancaran proses belajar mengajar, serta sangat membantu dalam pencapaian prestasi belajar yang memuaskan.

Kekurangaktifan siswa yang terlibat dalam proses pembelajaran dapat terjadi karena metode yang digunakan kurang melibatkan aktivitas siswa secara langsung. Pembelajaran di kelas masih banyak didominasi oleh guru sehingga kurang mampu membangun persepsi, minat, dan sikap siswa yang lebih baik. Kebanyakan anak didik mengalami kebosanan dikarenakan model pembelajaran yang berpusat pada guru sehingga kurangnya minat dan sikap siswa tersebut berdampak terhadap prestasi belajar yang secara umum kurang memuaskan.

Sekolah adalah lembaga formal dalam dunia pendidikan sebagai wahana untuk mencerdaskan kehidupan bangsa dan menghasilkan sumber daya manusia yang berkualitas. Oleh karena itu, pemerintah dengan berbagai upaya berusaha untuk meningkatkan kualitas pendidikan dengan memperbaharui kurikulum sesuai dengan perkembangan zaman, menambah sarana dan prasarana pendidikan, meningkatkan kualitas guru dan sebagainya.

Dalam pelajaran IPS, dengan materi pelajaran yang cukup padat dan sering berganti materi karena mengikuti perkembangan Kurikulum, juga menjadi beban yang cukup berat bagi siswa untuk dapat berprestasi secara maksimal. Siswa kurang berminat dalam mengikuti pelajaran IPS, hasil yang diperoleh selalu kurang sesuai dengan yang diharapkan.

Mata Pelajaran IPS bertujuan untuk mengenal konsepkonsep dan kehidupan masyarakat dan lingkungannya serta memiliki kemampuan dasar untuk berpikir logis dan kritis dalam memecahkan masalah yang terjadi dimasyarakat.

Melihat kondisi riil di sekolah dan memahami tujuan yang diharapkan dalam pembelajaran IPS, perlu dilakukan upaya secara serius dan terus menerus agar kegiatan pembelajaran dapat berjalan dengan baik. Sehingga aktifitas belajar semakin meningkat dan prestasi belajar siswa juga semakin sesuai dengan yang diharapkan semua pihak.

Tetapi melihat kenyataan dewasa ini apa yang menjadi harapan guru terhadap proses pembelajaran dikelas masih sangat jauh dari yang diharapkan. Berbagi metode dan 
strategi telah dilakukan namun partisipasi atau aktifitas siswa sangat kurang sehingga apa yang menjadi sasaran atau tujuan pembelajaran tidak dapat dicapai.

Kondisi tersebut juga terjadi pada siswa kelas IX-A SMP Negeri 1 Tambangan pada semester genap tahun pelajaran 2014/2015. Dimana dalam pengamatan awal penulis melihat bahwa hanya sekitar $57 \%$ siswa yang aktif dalam proses pembelajaran. Untuk mengatasi hal tersebut diperlukan usaha dari guru untuk dapat meningkatkan aktifitas belajar siswa kearah yang lebih menyenangkan dengan jalan memilih metode atau strategi pembelajaran yang tepat.

Berdasarkan

permasalahan yang ada, maka guru/peneliti merasa perlu untuk mengadakan penelitian terhadap strategi pembelajaran berkaitan dengan model pembelajaran yang digunakan oleh guru. Dalam hal ini, peneliti sepakat untuk menerapkan model pembelajaran kooperatif TPS (Think Pair Share). Berdasarkan Pembelajaran Kooperatif, peneliti ingin mengembangkan model TPS untuk meningkatkan penguasaan materi dan keaktifan siswa dalam proses pembelajaran yang akan berpengaruh pada prestasi belajar siswa dalam mengolah, mencari, dan mendiskusikan dengan teman dalam kelompok kecil.

Satu metode yang dapat digunakan untuk memecahkan masalah tersebut adalah penerapan Think-Pair-Share (TPS). Metode ini dikembangkan oleh Frank Lyman dan rekan-rekan dari Universitas Maryland pada tahun 1985. Keunggulan dari metode TPS adalah mudah untuk diterapkan pada berbagai tingkat kemampuan berpikir dan dalam setiap kesempatan. Siswa diberi waktu lebih banyak berpikir, menjawab, dan saling membantu satu sama lain. Prosedur yang digunakan juga cukup sederhana. Bertanya kepada teman sebaya dan berdiskusi kelompok untuk mendapatkan kejelasan terhadap apa yang telah dijelaskan oleh guru bagi siswa tertentu akan lebih mudah dipahami. Diskusi dalam bentuk kelompokkelompok kecil ini sangat efektif untuk memudahkan siswa dalam memahami materi dan memecahkan suatu permasalahan. Dengan cara seperti ini, siswa diharapkan mampu bekerjasama, saling membutuhkan, dan saling bergantung pada kelompok-kelompok kecil secara kooperatif.

Berdasarkan latar belakang masalah di atas, maka dapat diidentifikasi beberapa masalah sebagai berikut:

a. Siswa tidak terlalu berminat terhadap mata pelajaran IPS Terpadu karena dirasa kurang menarik, sehingga suara kelas cukup gaduh.

b. Guru merasa kesulitan dalam menerapkan model pembelajaran yang tepat untuk meningkatkan minat dan pemahaman siswa terhadap mata pelajaran IPS Terpadu. 
c. Siswa kurang aktif dalam pembelajaran mata pelajaran IPS Terpadu yang biasa dilakukan, siswa cenderung tidak mempergunakan kesempatan untuk bertanya tentang kesulitan yang mereka hadapi.

d. Hasil belajar yang tercermin dari prestasi siswa belum menunjukkan hasil yang maksimal, dengan ditandai nilai rata-rata kelas untuk mata pelajaran IPS Terpadu rendah.

Sesuai dengan judul penelitian dan permasalahan yang akan dibahas dalam penelitian ini, maka penulis membatasi masalah ini yaitu:

a. Model pembelajaran yang digunakan adalah model pembelajaran kooperatif tipe Think Pair Share (TPS).

b. Materi pokok dalam penelitian ini adalah hubungan manusia dengan bumi.

c. Subjek penelitian ini adalah siswa kelas IX-A SMP Negeri 1 Tambangan semester genap Tahun Pelajaran 2014/2015.

d. Kurikulum yang digunakan adalah KTSP.

Berdasarkan batasan masalah yang telah dikemukakan di atas maka masalah dalam penelitian ini dapat dirumuskan yaitu : a. Apakah Penerapan Model Pembelajaran Kooperatif Tipe Think Pair Share (TPS) dapat memperbaiki aktivitas belajar siswa pada mata pelajaran IPS Terpadu dengan materi pokok hubungan manusia dengan bumi di kelas IX-A SMP Negeri 1 Tambangan semester genap tahun pelajaran 2014/2015?

b. Apakah Penerapan Model Pembelajaran Kooperatif Tipe Think Pair Share (TPS) dapat memperbaiki hasil belajar siswa pada mata pelajaran IPS Terpadu dengan materi pokok hubungan manusia dengan bumi di kelas IX-A SMP Negeri 1 Tambangan semester genap tahun pelajaran 2014/2015?

Metode pemecahan masalah dalam penelitian ini yaitu dengan menerapkan model pembelajaran kooperatif tipe Think-Pair-Share. Dengan model pembelajaran ini diharapkan dapat meningkatkan aktivitas daan hasil belajar siswa dalam pembelajaran IPS Terpadu dengan materi pokok hubungan manusia dengan bumi.

Dari rumusan masalah tersebut tujuan dari penelitian ini adalah :

a. Untuk mengetahui apakah dengan implementasi model pembelajaran kooperatif tipe Think Pair Share (TPS) dapat memperbaiki aktivitas belajar 
siswa pada mata pelajaran IPS Terpadu dengan materi pokok hubungan manusia dengan bumi, di kelas IX-A SMP Negeri 1 Tambangan semester genap tahun pelajaran 2014/2015.

b. Untuk mengetahui apakah dengan implementasi model pembelajaran kooperatif tipe Think Pair Share (TPS) dapat memperbaiki hasil belajar siswa pada mata pelajaran IPS Terpadu dengan materi pokok hubungan manusia dengan bumi di kelas IX-A SMP Negeri 1 Tambangan semester genap tahun pelajaran 2014/2015.

\section{METODOLOGI PENELITIAN}

Tempat penelitian adalah tempat yang digunakan dalam melakukan penelitia $\mathrm{n}$ untuk memperoleh data yang diinginkan. Penelitian ini dilakukan di SMP Negeri 1 Tambangan yang bertempat di Desa Laru Baringi Kecamatan Tambangan Kabupaten Mandailing Natal. Pelaksanaannya pada bulan Januari sampai dengan April Tahun Pelajaran 2014/2015. Pengambilan data dilakukan pada akhir bulan Pebruari 2015.

Penelitian Tindakan Kelas (PTK) adalah suatu bentuk penelitian yang dilaksanakan oleh para praktisi (termasuk guru) untuk memecahkan masalah-masalah yang dihadapi dalam melaksanakan tugas pokoknya, bagi guru adalah pelaksanaan KBM (Agung Purwadi : 1998). Satu pembeda PTK dengan penelitian jenis lain adalah obyeknya. Obyek penelitian PTK dalam pendidikan adalah pelaksanaan KBM dengan tujuan untuk memperbaiki pelaksanaan KBM tersebut.

PTK bagi guru merupakan refleksi diri dengan tujuan menyempurnakan KBM, meningkatkan pengertian dan pemahaman tentang situasi dan kondisi ketika KBM dilaksanakan, dan dalam melaksanakan PTK guru tidak meninggalkan KBM nya, sebab PTK dilaksanakan terintegrasi dalam KBM (Kasihani KE, Dr, Hj. : 1988).

Dengan mempertimbangkan perolehan nilai terendah untuk seluruh kelas IX SMP Negeri 1 Tambangan adalah pada kelas IX, maka subjek yang digunakan dalam penelitian ini adalah seluruh siswa kelas IX-A SMP Negeri Tambangan Tahun Pelajaran 2014/2015, dengan jumlah siswa yang terikut dalam penelitian sebanyak 20 orang.

\section{Variabel Penelitian}

Data penelitian ini ada dua variabel yang akan diteliti yaitu :

\section{a. Variabel bebas}

Variabel bebas dalam penelitian ini adalah Model pembelajaran kooperatif tipe TPS

\section{b. Variabel terikat}

Variabel terikat dalam penelitian ini adalah aktivitas belajar siswa pada materi pokok Hubungan manusia dengan bumi. 


\section{Alat Pengumpul Data}

Alat pengumpul data dalam penelitian ini adalah:

\section{Tes hasil belajar.}

Tes hasil belajar ini berjumlah 20 soal bentuknya pilihan ganda. Klasifikasi soal menurut teori Bloom $\mathrm{C}_{1}$ ada 10 soal, $\mathrm{C}_{2}$ ada 6 soal dan soal $\mathrm{C}_{5}$ ada 4 soal. Melihat gambaran klasifikasi soal memliki gambaran sesuai dengan teori Bloom, dan tingkat kesukarannya juga berbeda. Tes hasil belajar yang memiliki kasifikasi dan tingkat kesukarannya berbeda. Tes hasil belajar ini digunakan untuk mengetahui kemampuan awal dan kemampuan akhir siswa. Setelah kegiatan belajar mengajar dilaksanakan (Siklus I), maka dilakukan tes hasil belajar disebut formatif I dengan jumlah 10 soal. Akhir KBM pada Siklus II, dilakukan tes hasil belajar terakhir atau disebut formatif II dengan jumlah 10 soal, dan soalnya diambil dari soal pretes sesuai dengan materi pembelajaran. Tes hasil belajar ini sesuai klasifikasi/kisi-kisi tes dan dapat dilihat pada Tabel 3.1.
Tabel 3.1 : Tabel Kisi-Kisi Tes

Hasil Belajar

\begin{tabular}{|c|c|c|c|c|c|}
\hline \multirow{2}{*}{ No. Soal } & \multicolumn{5}{|c|}{ Klasifikasi / Kategori } \\
\hline & $\mathrm{C}_{1}$ & $\mathrm{C}_{2}$ & $\mathrm{C}_{3}$ & $\mathrm{C}_{4}$ & $\mathrm{C}_{5}$ \\
\hline 01. & $\sqrt{ }$ & & & & \\
\hline 02. & & $\sqrt{ }$ & & & \\
\hline 03. & & $\sqrt{ }$ & & & \\
\hline 04. & $\sqrt{ }$ & & & & \\
\hline 05. & $\sqrt{ }$ & & & & \\
\hline 06. & & $\sqrt{ }$ & & & \\
\hline 07. & & $\sqrt{ }$ & & & \\
\hline 08. & & & & & $\sqrt{ }$ \\
\hline 09. & $\sqrt{ }$ & & & & \\
\hline 10. & $\sqrt{ }$ & & & & \\
\hline 11. & $\sqrt{ }$ & & & & \\
\hline 12. & & $\sqrt{ }$ & & & \\
\hline 13. & & $\sqrt{ }$ & & & \\
\hline 14. & $\sqrt{ }$ & & & & \\
\hline 15. & $\sqrt{ }$ & & & & \\
\hline 16. & & $\sqrt{ }$ & & & \\
\hline 17. & & $\sqrt{ }$ & & & \\
\hline 18. & & & & & $\sqrt{ }$ \\
\hline 19. & $\sqrt{ }$ & & & & \\
\hline 20. & $\sqrt{ }$ & & & & \\
\hline Jumlah & & & & & \\
\hline & & & & \\
\hline
\end{tabular}

Keterangan :
$\mathrm{C}_{1}$ : Pengetahuan
$\mathrm{C}_{2}$ : Pemahaman
$\mathrm{C}_{3}$ : Aplikasi
$\mathrm{C}_{4}$ : Analisis
$\mathrm{C}_{5}$ : Sintesis
$\mathrm{C}_{6}$ : Evaluasi

Penelitian ini berbentuk Penelitian Tindakan Kelas (PTK). PTK pertama kali diperkenalkanoleh psikologi sosial Amerika yang bernama Kurt Lewin pada tahun 1946 (Aqib, 2006 :13). Penelitian tindakan kelas adalah penelitian yang 
dilakukan oleh guru di kelas atau disekolah dengan penekanan pada penyempurnaan atau peningkatan proses pembelajaran. Menurut Lewin dalam Aqib (2006 : 21) menyatakan bahwa dalam satu Siklus terdiri atas empat langkah, yaitu perencanaan (planning), tindakan (acting), observasi (observing) dan refleksi (reflecting).

Adapun desain pelaksanaan PTK yang penulis rencanakan dalam penelitian adalah dalam dua Siklus PTK seperti gambar berikut :

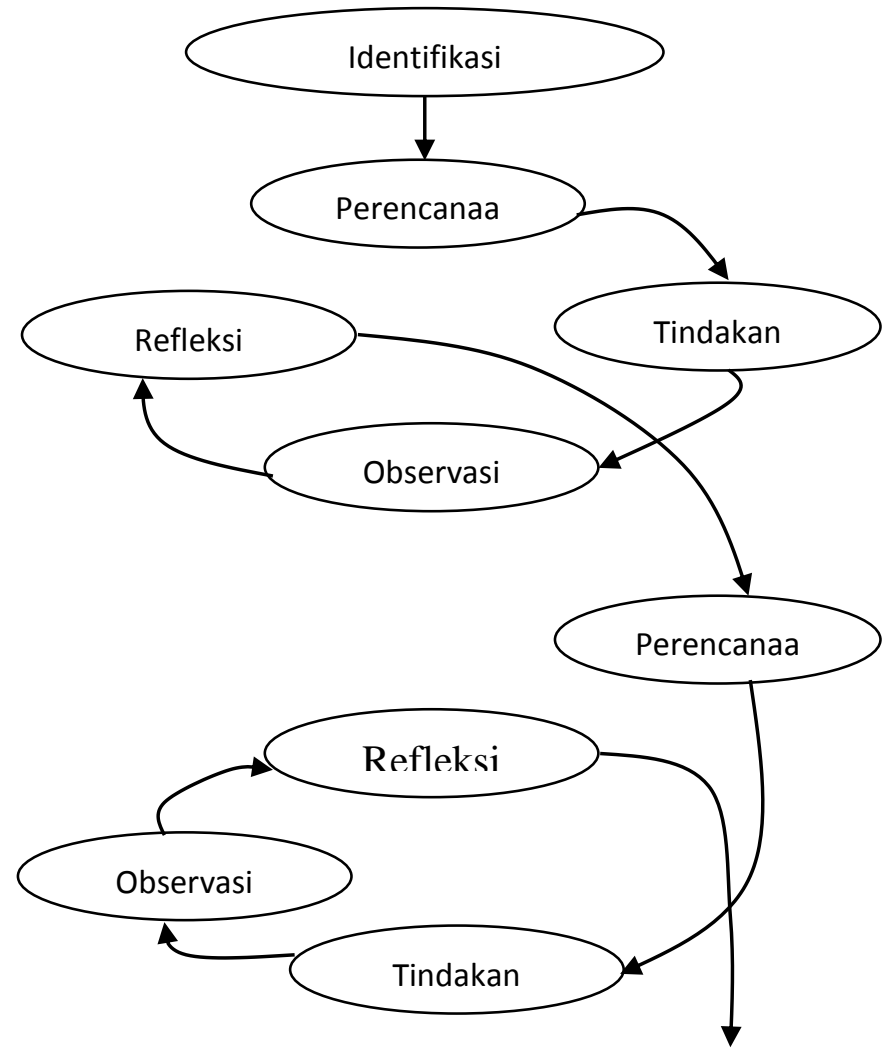

Gambar 3.1 : Spiral Tindakan Kelas (Hopkins dalam Aqib, 2006 : 31)

\section{Prosedur Penelitian}

Berdasarkan informasi yang penulis dapatkan, bahwa aktivitas belajar siswa pada mata pelajaran IPS Terpadu masih rendah, maka prosedur penelitian yang penulis rencanakan dalam memperbaiki aktivitas dan menuntaskan hasil belajar tersebut adalah sebagai berikut :

Tahap Perencanaan

a. Melakukan konsultasi

b. Membuat Rencana Pelaksanaan Pembelajaran (RPP)

c. Menyusun soal tes diagnostik

d. Menyusun lembar observasi aktivitas siswa dalam pembelajaran dan menentukan sampel penelitian

e. Melakukan tes diagnostik

f. Mengolah hasil tes diagnostik

\section{Tahap Tindakan}

a. Melaksanakan Rencana Pelaksanaan

Pembelajaran. Dalam tahap ini, sebelum guru memulai materi pembelajaran, maka guru mencipptakan suasana yang kondusif. Melakukan evaluasi hasil pembelajaran, yaitu dengan cara memberikan soal yang sama pada tes diagnostik untuk mengetahui hasil belajar.

b. Melakukan pengolahan tes hasil belajar. Ini dilakukan untuk melihat hasil belajar siswa dan sebagai informasi atau 
referensi jika terjadi kesalahan.

\section{Tahap Observasi}

Selama proses pelaksanaan pembelajaran berlangsung, peneliti juga melakukan pengamatan (observasi) terhadap perilaku atau respon siswa yang dibantu oleh dua orang pengamat.

\section{Tahap Refleksi}

a. Mengadakan refleksi,. Dari hasil analisis Siklus I, bahwa masih terdapat beberapa siswa yang memperoleh hasil belajar dibawah nilai ketuntasan.

b. Melakukan Siklus II. Adapun sub materi pokok yang dipelajari adalah sub materi pokok yang belum dipahami siswa. Dalam pembelajaran ini dibarengi dengan pengamatan yang dilakukan oleh pengamat terhadap aktivitas belajar siswa. Setelah selesai, maka dilakukan evaluasi hasil pembelajaran pada Siklus II.

c. Melakukan refleksi. Dari hasil analisis Siklus II ternyata hasil belajar siswa telah mencapai ketuntasan dan begitu juga dengan penguasaan siswa terhadap tiap sub materi pokok maka diperoleh hasil belajar siswa minimal mencapai KKM.

Teknik Analisis Data

Untuk mengetahui keefektivan suatu model dalam kegiatan pembelajaran perlu diadakan analisa data. Pada penelitian ini menggunakan teknik analisis deskriptif kualitatif, yaitu suatu metode penelitian yang bersifat menggambarkan kenyataan atau fakta sesuai dengan data yang diperoleh dengan tujuan untuk mengetahui hasil belajar yang dicapai siswa juga untuk memperoleh gambaran aktivitas siswa selama proses pembelajaran.

Untuk menganalisis tingkat keberhasilan atau persentase keberhasilan siswa setelah proses belajar mengajar setiap siklusnya dilakukan dengan cara memberikan evaluasi berupa soal tes tertulis pada setiap akhir siklus. Analisis ini dihitung dengan menggunakan statistik sederhana yaitu:

a. Untuk menilai hasil belajar atau tes formatif

Peneliti melakukan penjumlahan nilai yang diperoleh siswa, yang selanjutnya dibagi dengan jumlah siswa yang ada di kelas tersebut sehingga diperoleh rata-rata tes formatif dapat dirumuskan:

$$
\bar{X}=\frac{\sum X}{\sum N}
$$


Dengan

$\bar{X} \quad=$ Nilai rata-rata

$\Sigma \mathrm{X}=$ Jumlah semua nilai siswa

$\Sigma \mathrm{N}=$ Jumlah siswa

b. Untuk ketuntasan belajar Ada dua kategori ketuntasan belajar yaitu secara perorangan dan secara klasikal. Seorang siswa telah tuntas belajar bila hasil tesnya telah mencapai KKM, dan kelas disebut tuntas belajar bila di kelas tersebut terdapat $85 \%$ yang telah mencapai daya serap lebih dari atau sama dengan KKM. KKM IPS Terpadu kelas IX-A SMP Negeri 1 Tambangan sebesar 75. Untuk menghitung persentase ketuntasan belajar digunakan rumus sebagai berikut:

$P=\frac{\sum \text { Siswa.yang.tuntasbelajar }}{\sum \text { Siswa }} \times 100 \%$

c. Untuk lembar observasi

a) Lembar observasi $\begin{array}{lr}\text { pengelolaan } & \text { model } \\ \text { pembelajaran } & \text { kooperatif }\end{array}$ tipe TPS.

Untuk menghitung lembar observasi

pengelolaan model pembelajaran kooperatif tipe Think Pair Share (TPS) digunakan rumus sebagai berikut:

$\bar{X}=\frac{P_{1}+P_{2}}{2}$
Dimana:

$\mathrm{P}_{1}=$ pertemuan 1

$\mathrm{P}_{2}=$ pertemuan 2

b. Lembar observasi aktivitas guru dan siswa Untuk menghitung lembar observasi aktivitas guru dan siswa digunakan rumus sebagai berikut:

$$
\%=\frac{\bar{X}}{\sum X} x 100 \%
$$

dengan

$$
\bar{X}=\frac{\text { jumlahhasil.pengamatan }}{\text { jumlahpengamat }}=\frac{P_{1}+P_{2}}{2}
$$

Dimana:

$\%=$ Persentase pengamatan

$\bar{X} \quad=$ Rata-rata

$\sum \bar{X}=$ Jumlah rata-rata

$\mathrm{P}_{1} \quad=$ Pengamat 1

$\mathrm{P}_{2} \quad=$ Pengamat 2

Indikator keberhasilan yang ditetapkan dalam penelitian ini adalah ketika ketuntasan hasil belajar siswa secara klasikal mencapai $85 \%$. Atau paling tidak $85 \%$ siswa dalam kelas mendapatkan perolehan nilai mencapai KKM IPS Terpadu kelas IX-A SMP Negeri 1 Tambangan sebesar 75 .

\section{HASIL PENELITIAN DAN} PEMBAHASAN

Sebelum dilaksanakannya penelitian dengan menerapkan model 
pembelajaran Think-Pair-Share (TPS) pada mata pelajaran IPS Terpadu. Peneliti lebih dulu melakukan observasi awal guna untuk mengetahui keadaan awal aktivitas dan hasil belajar siswa sebelum diadakannya penelitian. Kondisi belajar mengajar di kelas kurang meningkatkan aktivitas belajar siswa karena Guru sebagai pengelola pembelajaran kurang bervariasi di dalam penggunaan metode pembelajaran dan model pembelajaran yang digunakan oleh guru kurang bervariasi. Hal ini dapat dilihat dari keberanian siswa bertanya kepada guru hanya didominasi oleh siswa-siswa yang pintar.

Penggunaan metode dan model pembelajaran yang monoton dalam pembelajaran IPS Terpadu menjadikan siswa pasif sehingga pencapaian hasil belajar terlihat kurang optimal. Pada saat pembelajaran berlangsung sebagian besar peserta didik ramai sendiri, tidak ada siswa yang mengajukan pertanyaan atau memberikan tanggapan terhadap materi yang disampaikan oleh guru, bahkan ketika guru memberi kesempatan untuk bertanya, tidak ada yang bertanya.

\section{Kegiatan Pra Tindakan}
a. Identifikasi permasalahan pembelajaran

Sebelum proses penelitian dilaksanakan, peneliti mengadakan observasi awal pada bulan Januari
2015 untuk mengetahui keberadaan aktivitas belajar siswa sebelum menerapkan model pembelajaran Think-Pair-Share (TPS).

b. Perencanaan kegiatan sebelum penelitian

a) Urutan tindakan

Survei dan penjajakan

Survei dan penjajakan dilakukan secara langsung untuk mengetahui kemungkinan dan ketersediaan sekolah yang bersangkutan untuk dijadikan tempat penelitian. Tujuan survei yang lain adalah untuk mendapatkan informasi baik fisik maupun non fisik keadaan sekolah dan sarana pembelajaran.

Perijinan

Perijinan diperoleh dengan prosedur yang ada dengan ijin dan rekomendasi lembaga terkait untuk perijinan ke lapangan. Pada penelitian ini, peneliti meminta surat ijin penelitian kepada kepala sekolah SMP Negeri 1 Tambangan.

b) Rancangan Pelaksanaan Penelitian

Untuk melaksanakan penelitian, diperlukan suatu rancangan yang dijadikan pedoman dalam proses pembelajaran. Rencana penelitian ini merupakan suatu rancangan model pembelajaran Think-Pair-Share (TPS) dengan upaya meningkatkan aktivitas siswa dalam belajar sehingga dapat mencapai tujuan yang diharapkan.

Secara umum pada model pembelajaran Think-Pair-Share (TPS), Tugas guru selama proses pembelajaran berlangsung adalah menyampaikan tujuan pembelajaran 
sejelas-jelasnya, memantau aktivitas siswa dan memberi bantuan kepada siswa untuk memaksimalkan proses pembelajaran, mengevaluasi kerja siswa, menerangkan materi pelajaran dan membantu siswa untuk mampu berpikir dan membagi pengetahuannya kepada siswa yang lain. Model pembelajaran ThinkPair-Share (TPS) menuntut siswa agar mampu berpikir, menganalisi masalah dan membagi kepada sesama teman.

Dalam desain pembelajaran ini peran guru selain sebagai fasilitator juga sebagai koordinator dan konsultan dalam memperdayakan siswa, artinya guru mempunyai kewajiban untuk mengamati siswa dalam proses pembelajaran. Sementara itu siswa dituntut untuk lebih aktif dalam berpikir, mempersiapkan dan membagi pengetahuan kepada sesama teman dengan penuh tanggung jawab.

\section{Pelaksanaan Tindakan}

Kurikulum yang diterapkan di SMP Negeri 1 Tambangan adalah Kurikulum Tingkat Satuan Pendidikan (KTSP). Kurikulum Tingkat Satuan Pendidikan (KTSP) merupakan sebuah kurikulum yang benar-benar dibuat oleh sekolah yang melibatkan unsur kepala sekolah, pembantu kepala sekolah, guru, konselor, komite sekolah, sehingga dengan sinerginya unsur-unsur tersebut akan menemukan kemudahan dalam proses penyusunan kurikulum. \begin{tabular}{ccr}
\multicolumn{2}{c}{ Pengambilan data untuk } \\
penelitian tindakan kelas ini \\
dilakukan di SMP Negeri 1
\end{tabular} Tambangan, dan waktunya mulai bulan Pebruari 2015. Pengambilan datanya dilakukan empat kali pertemuan (4 RPP) dibagi menjadi dua Siklus, yaitu Siklus I dan Siklus II. Siklus I, terdiri dari dua kali pertemuan, sedangkan Siklus II juga dilakukan dua kali pertemuan. Masing-masing Siklus terdiri dari 4 tahapan, yaitu: (1) perencanaan tindakan, (2) pelaksanaan tindakan, (3) observasi dan interpretasi, dan (4) analisis dan refleksi tindakan.

Data penelitian yang diperoleh berupa hasil tes formatif siswa pada setiap siklus dan data pengamatan aktivitas siswa setelah menggunakan model pembelajaran Think-Pair-Share (TPS). Sebelum melaksanakan KBM Siklus I, peneliti memberikan tes hasil diagnostik dalam pretes dengan hasil nilai tertinggi 60 dan terendah 30 dengan rata-rata kelas 44.25 sehingga ketuntasan klasikal $0 \%$ atau pengetahuan awal siswa terhadap materi ini sangat rendah. Tabel hasil data pretes siswa dapat dilihat pada tabel dibawah ini: 
Tabel 4.1 Distribusi Hasil Pretest

\begin{tabular}{|c|c|c|c|}
\hline Nilai & Frekuensi & Ketuntasan & $\begin{array}{c}\text { Rata- } \\
\text { rata }\end{array}$ \\
\hline 30 & 2 & - & \multirow{2}{*}{} \\
\cline { 1 - 3 } 35 & 2 & - & \multirow{2}{*}{44.25} \\
\hline 40 & 8 & - & \\
\hline 50 & 3 & - & \\
\hline 55 & 3 & - & \\
\hline 60 & 2 & - & \\
\hline Jumlah & 20 & $0 \%$ & \\
\hline
\end{tabular}

Data hasil pretes ini dapat disajikan dalam grafik histogram pada Gambar 4.1 berikut ini.

\section{Grafik Pretes}

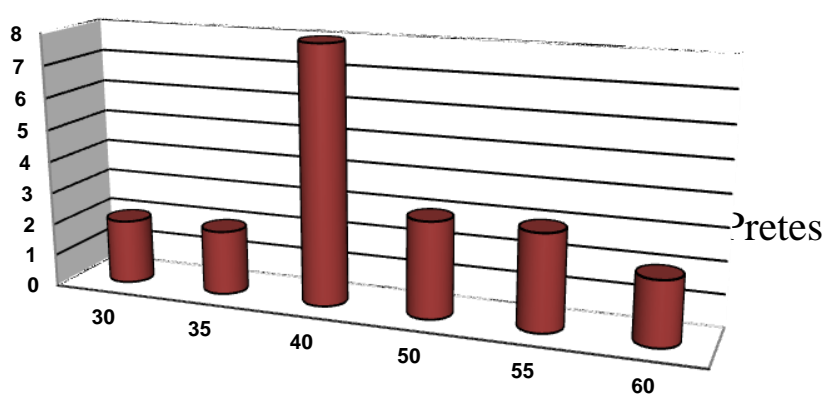

\begin{tabular}{|c|c|c|c|c|c|c|}
\cline { 2 - 7 } \multicolumn{1}{c|}{} & 30 & 35 & 40 & 50 & 55 & 60 \\
\hline aFrekuensi & 2 & 2 & 8 & 3 & 3 & 2 \\
\hline
\end{tabular}

\section{Siklus I \\ Pertemuan 1}

Pada hari Rabu tanggal 18 Pebruari 2015 pada jam pelajaran 1 dan 2 di kelas IX-A guru masuk ke kelas dan langsung menyapa siswa dengan mengucapkan, "Selamat pagi", siswa menjawab "pagi pak" dan kemudian guru mengucapkan apa kabar? siswa menjawab " Luar biasa”. Karena dipertemuan sebelumnya, ada tugas yang diberikan guru maka guru menyuruh siswa untuk mengumpulkan tugas tersebut dan guru pun mengatakan siapa yang tidak mengerjakan tugas silahkan maju. Ternyata ada dua orang siswa yang tidak mengerjakan tugas silahkan maju. Ternyata ada dua orang siswa yang tidak mengerjakan tugasnya yakni Ali Musa dan Herianto. Guru bertanya mengapa mereka tidak mengerjakan tugas, lalu Wahyu menjawab "tidak mengerti mengerjakannya pak!” dan Ali juga menjawab seperti yang dijawab Wahyu. Sebelum guru memulai pelajaran yang baru terlebih dahulu guru mengulas kembali pelajaran sebelumnya, kemudian guru bertanya apakah mereka sudah mengerti lalu Pitri dan Nurmina menjawab "sudah pak" kemudian guru memberikan masing-masing satu soal untuk dikerjakan di papan tulis, setelah soal selesai dikerjakan, guru menilai bahwa soal yang dikerjakan sudah benar, lalu guru mempersilahkan Ali dan Herianto untuk duduk kembali.

Guru memulai pelajaran baru dengan menjawab judul "Bentuk-bentuk muka bumi pada peta" dipapan tulis. Guru menyuruh siswa untuk membentuk kelompok dengan masing-masing kelompok terdiri dari 4 orang dan guru memberikan soal kepada masing-masing kelompok untuk didiskusikan, selama 20 menit siswa berdiskusi tentang hubungan manusia dengan bumi, setelah itu setiap kelompok disuruh maju satu orang untuk mewakili satu kelompok untuk mempresentasikan kedepan.

Sesudah semua perwakilan kelompok mempresentasikan hasil diskusi maka guru menerangkan/menjelaskan tentang hubungan manusia dengan bumi. Siswa memperhatikan penjelasan guru meskipun banyak diantaranya masih ribut dan tidak mendengarkan. Lalu guru memberikan 2 soal untuk dikerjakan di buku masingmasing siswa, ternyata siswa sudah mampu untuk mengerjakan kedua soal tersebut. Karena waktu tinggal 10 menit lagi, guru memberikan tugas untuk dikerjakan dirumah, dan bel berbunyi tanda bahwa les 1 dan 2 selesai, lalu guru menyapa siswa, "Selamat pagi", siswa pun menjawab, "Selamat pagi pak", dan gurupun keluar dari kelas.

\section{Observasi}

Selama kegiatan berlangsung diadakan observasi secara langsung terhadap aktivitas siswa dalam pembelajaran IPS Terpadu oleh observer. Setelah guru selesai 
menyajikan materi pembelajaran tentang siswa bekerja dalam kelompok, peneliti memberikan instrument aktivitas siswa kepada pengamat. Untuk merekam aktivitas siswa dilakukan oleh dua pengamat sesuai dengan instruksi oleh peneliti. Pada pertemuan pertama ini jumlah siswa yang masuk sebanyak 20 siswa (100\%). Aktivitas siswa pada pertemuan pertama ini masih rendah dan belum sesuai dengan yang diharapkan. Siswa masih pasif dalam mengikuti pembelajaran. Pada saat melakukan kegiatan diskusi, banyak siswa sibuk sendiri dan mengobrol dengan teman-temannya, siswa dalam bertanya dan menjawab asalasalan. Pada pertemuan pertama ini, hanya 3 orang siswa yang memberikan tanggapan pada hasil diskusi kelompok yang dipresentasikan. Hasil observasi pada pertemuan pertama ini dapat dilihat pada tabel berikut ini.
Tabel 4.2. Aktivitas siswa pada pertemuan 1,siklus I

\begin{tabular}{|c|l|c|c|c|}
\hline & \multicolumn{4}{|c|}{ Siklus I } \\
\hline No & \multicolumn{1}{|c|}{ Aktivitas } & Jumlah & Skor & Persentase \\
\hline 1 & Menulis/membaca & 21 & 10.5 & $26.25 \%$ \\
\hline 2 & Mengerjakan & 11 & 5.5 & $13.75 \%$ \\
\hline 3 & $\begin{array}{l}\text { Bertanya pada } \\
\text { teman }\end{array}$ & 17 & 8.5 & $21.25 \%$ \\
\hline 4 & $\begin{array}{l}\text { Bertanya pada } \\
\text { guru }\end{array}$ & 17 & 8.5 & $21.25 \%$ \\
\hline 5 & $\begin{array}{l}\text { Yang tidak } \\
\text { relevan dengan } \\
\text { KBM }\end{array}$ & 14 & 7 & $17.5 \%$ \\
\hline & JUMLAH & 80 & 40 & $100 \%$ \\
\hline
\end{tabular}

Pada tabel di atas dapat ditunjukkan bahwa aktivitas yang paling besar adalah aktivitas menulis dan membaca sebesar $26.25 \%$. Hal ini karena siswa tidak tahu apa yang harus dikerjakannya dan belum terbiasa untuk menggunakan pikirannya untuk mencari tahu sehingga siswa lebih suka menulis atau membaca dan bertanya kepada guru. Aktivitas yang paling rendah adalah aktivitas mengerjakan yaitu $17.5 \%$, hal ini disebabkan karena tidak ada keberanian untuk bertanya kepada guru.

\section{Pertemuan 2}

a) Pelaksanaan tindakan

Pada hari Kamis tanggal 19 Pebruari 2015 pada jam 6 dan 7 pukul 11.55-13.10 WIB di kelas IX-A, guru masuk ke kelas dan langsung menyapa siswa dengan mengucapkan, "Selamat siang", siswa menjawab "Siang pak", kemudian guru menyapa dengan ucapan apa kabar, siswa menjawab " luar biasa". Guru bertanya " ada yang tidak hadir?" dan ketua kelas menjawab 
" hadir semua pak". Lalu guru menyuruh siswa untuk mengumpulkan tugas yang diberikan hari rabu,dan siswapun mengumpulkannya dimeja guru.

Guru memulai pelajaran dengan menulis judul dipapan tulis, guru menyuruh siswa untuk membuat kelompok yang terdiri dari 4 orang per kelompok dan membagikan LKS kepada masing-masing kelompok untuk didiskusikan bersama sesuai dengan kelompok masing-masing dan diberikan waktu untuk berdiskusi selama 20 menit kemudian setelah selesai berdiskusi sesuai waktu yang sudah ditentukan, guru menyuruh masing-masing siswa perwakilan kelompok supaya maju untuk mempresentasikan hasil diskusi tersebut, ternyata setelah selesai presentase guru menilai bahwa hasilnya belum itu belum dikuasai siswa $100 \%$ sehingga guru menerangkan kembali materi pelajaran sampai masing-masing siswa benar-benar mengerti judul tersebut, guru pun memberikan contohcontoh soal yang ada didalam buku paket halaman.

Kemudian guru memberikan tugas untuk dikerjakan dirumah sebanyak 2 soal tentang Diagram Bentuk muka bumi daratan dan dasar laut, dan teknik/Cara pengambaran bentuk muka bumi pada petakarena waktu habis dan belpun sudah berbunyi menandakan pergantian jam, maka guru menyampaikan salam kepada siswa dengan ucapan selamat berjumpa minggu depan dan selamat siang. Siswa menjawab salam tersebut dengan mengucapkan selamat siang pak. Lalu guru keluar dari kelas tersebut.

\section{b) Observasi}

Selama kegiatan berlangsung diadakan observasi secara langsung terhadap aktivitas siswa dalam pembelajaran IPS Terpadu. Pada pertemuan kedua ini ini jumlah siswa yang masuk sebanyak 20 (100\%). Aktivitas siswa pada pertemuan kedua ini mengalami perubahan yang lebih baik dari pertemuan sebelumnya, dimana siswa sudah mulai berani mengemukakan pendapat. Pertemuan kedua ini, masih terdapat kegiatan siswa yang tidak sesuai dengan KBM, misalnya pada saat diskusi kelompok masih ada beberapa siswa yang ngobrol dengan temannya, sementara siswa yang lain sedang mengerjakan tugas. Pengerjaan soal LKS saat diskusi kelompok didominasi oleh siswa yang pintar. Hasil observasi pada pertemuan kedua ini dapat dilihat pada tabel berikut ini:

\section{Tabel 4.3. Aktivitas siswa pada pertemuan 2, siklus I.}

\begin{tabular}{|c|c|c|c|c|}
\hline & \multicolumn{4}{|c|}{ Siklus I } \\
\hline No & Aktivitas & Jumlah & Skor & Persentase \\
\hline 1 & Menulis/membaca & 17 & 8.5 & $21.25 \%$ \\
\hline 2 & Mengerjakan & 13 & 6.5 & $16.25 \%$ \\
\hline 3 & $\begin{array}{l}\text { Bertanya pada } \\
\text { teman }\end{array}$ & 16 & 8 & $20 \%$ \\
\hline 4 & $\begin{array}{l}\text { Bertanya pada } \\
\text { guru }\end{array}$ & 17 & 8.5 & $21.25 \%$ \\
\hline 5 & $\begin{array}{l}\text { Yang tidak } \\
\text { relevan dengan } \\
\text { KBM }\end{array}$ & 17 & 8.5 & $21.25 \%$ \\
\hline JUN & $\mathrm{AH}$ & 80 & 40 & $100 \%$ \\
\hline
\end{tabular}

Setelah memperoleh datadata hasil observasi pada pertemuan 1 dan 2, selanjutnya akan dibandingkan aktivitas siswa dan nilai rata-rata antara siklus I dengan nilai rata-rata pretes kelas X-A SMP Negeri 1 Tambangan. Untuk lebih jelasnya dapat dilihat pada tabel di bawah ini: 
Tabel 4.4. Rata-rata aktivitas siswa pada siklus I pada pertemuan I dan II

\begin{tabular}{|c|l|c|c|c|}
\hline \multirow{2}{*}{ No } & \multirow{2}{*}{ Aktivitas } & \multicolumn{3}{c|}{ Siklus I } \\
\cline { 3 - 5 } & & Jumlah & Skor & Persentase \\
\hline 1 & Menulis/membaca & 38 & 10 & $23.75 \%$ \\
\hline 2 & Mengerjakan LKS & 24 & 6 & $15.00 \%$ \\
\hline 3 & Bertanya pada teman & 33 & 8 & $20.63 \%$ \\
\hline 4 & Bertanya pada guru & 34 & 9 & $21.25 \%$ \\
\hline 5 & $\begin{array}{l}\text { Yang tidak relevan dengan } \\
\text { KBM }\end{array}$ & 31 & 8 & $19.38 \%$ \\
\hline \multicolumn{2}{|c|}{ JUMLAH } & 160 & 40 & $100 \%$ \\
\hline
\end{tabular}

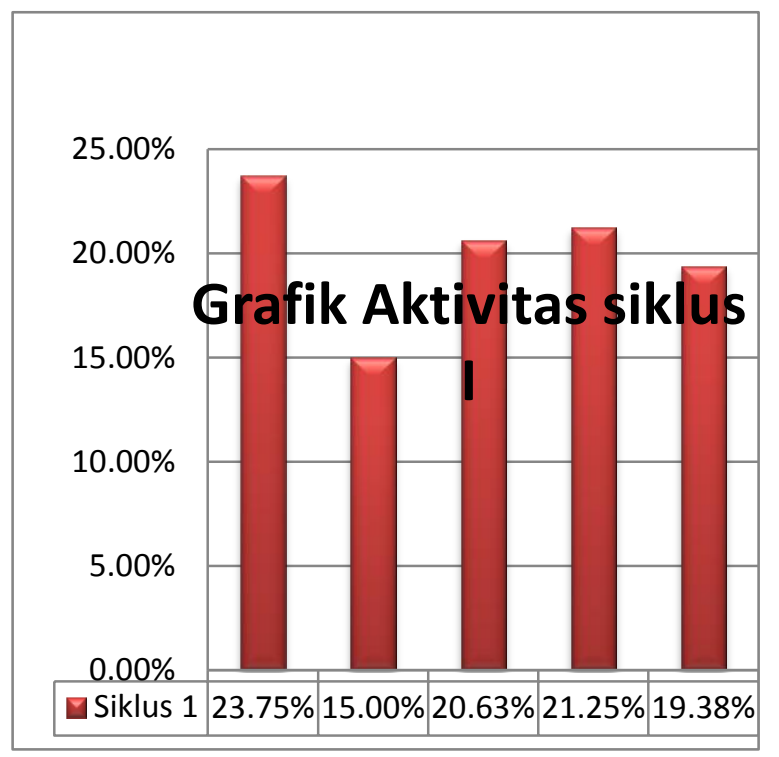

Gambar 4.2. Grafik aktivitas siswa Siklus I

Keterangan: 1. Menulis,membaca

2. Mengerjakan LKS

3. Bertanya pada teman

4. Bertanya pada guru

5. Yang tidak relevan

Pada siklus I, secara garis besar kegiatan belajar mengajar dengan model pembelajaran ThinkPair-Share (TPS) sudah dilaksanakan dengan baik. Pada akhir pertemuan siklus I diadakan tes untuk mengetahui sejauh mana peranan model pembelajaran berdasarkan masalah terhadap hasil belajar siswa, dari hasil tes tersebut akan dibandingkan dengan nilai pretes yang lalu. Adapun data hasil penelitian pada siklus I adalah sebagi berikut :

Tabel 4.5Distribusi Hasil Formatif I

\begin{tabular}{|c|c|c|}
\hline Nilai & Frekuensi & Rata-rata \\
\hline 40 & 1 & \multirow{7}{*}{74.00} \\
\hline 50 & 1 & \\
\hline 60 & 6 & \\
\hline 80 & 7 & \\
\hline 90 & 3 & \\
\hline 100 & 2 & \\
\hline Jumlah & 20 & \\
\hline
\end{tabular}

Pada Tabel 4.5 tersebut, nilai terendah Formatif I adalah 40 sebanyak 1 orang dan nilai tertinggi adalah 100 sebanyak 2 orang, dengan 12 orang mencapai nilai kriteria ketuntasan atau ketuntasan klasikal adalah sebesar $60 \%$. Nilai ini berada di sedikit bawah kriteria keberhasilan sehingga dapat dikatakan KBM Siklus I kurang berhasil memberi ketuntasan belajar dalam kelas. Nilai rata-rata kelas adalah 74.00. Data hasil Formatif I ini dapat disajikan kembali dalam grafik histogram sebagai berikut: 


\section{Grafik Formatif I}

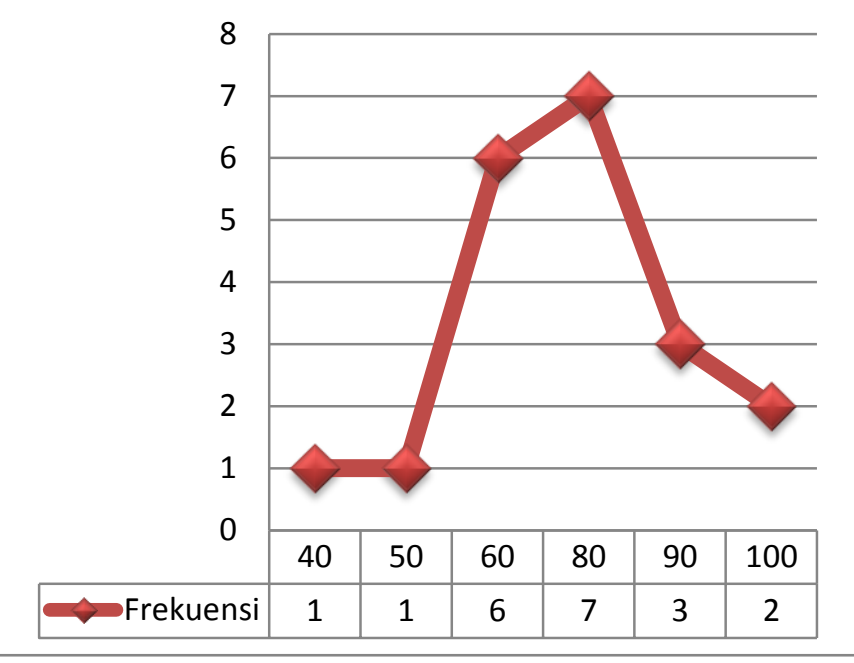

\section{Gambar .4.3. Grafik data hasil} Formatif I

Pengamatan terhadap pengelolaan pembelajaran dilkukan oleh dua orang pengamat sepanjang pembelajaran.

\section{Pertemuan 3}

KBM 3 dilakukan pada hari Sabtu 21 Pebruari 2015 pada les 4 dan 5 pukul 10.1511.35 WIB di kelas IX-A. Guru masuk ke kelas dengan menyapa siswa sambil senyum mengucapkan "Selamat siang", siswa menjawab dengan nada bersemangat "Siang pak", lalu guru menyapa lagi dengan ucapan "apa kabar?", siswa menjawab sambil mengangkat tangannya "luar biasa".

Guru mengabsen siswa, ternyata siswa di kelas tersebut tidak ada yang absen, lalu guru membuka pelajaran dan memotivasi siswa agar lebih semangat lagi dalam mengikuti pembelajaran. Guru menyampaikan indikator pembelajaran dan memberikan pertanyaan seputar materi yang akan disampaikan kepada siswa. Setelah itu guru memberikan contoh soal tentang Unsur-unsur fisik dan sosial kawasan Asia Tenggara, bentang alam di kawasan Asia Tenggara dan klim di kawasan Asia Tenggara.

Guru menyuruh siswa untuk membuat kelompok yang terdiri dari 4 orang perkelompok, dan guru memberikan soal kepada masing-masing kelompok untuk didiskusikan oleh kelompok tersebut, dan guru menentukan waktu diskusi sekitar 20 menit dengan memberikan soal sebanyak 4 soal. Dalam kegiatan diskusi kelompok guru membimbing dan mengawasi siswa yang mengalami kesulitan dalam kegiatan diskusi.

Setelah 20 menit guru menyuruh satu orang untuk perwakilan satu kelompok supaya maju untuk mempresentasikan hasil diskusi tersebut, ternyata dari hasil masingmasing kelompok sudah bisa menguasai materi sekitar $80 \%$, setelah seleaia presentase guru mempersilahkan seluruh siswa perwakilan tersebut untuk duduk kembali, dan selanjutnya guru menerangkan/menjelaskan kembali untuk memperkuat dan memperjelas pengetahuan siswa, dengan memberikan beberapa contoh. Kemudian guru memberikan soal sebanyak 2 soal untuk dikerjakan siswa, setelah guru menilai/mencek jawaban yang dikerjakan setiap siswa ternyata sudah benar $90 \%$.

Karena waktu tinggal 10 menit lagi guru memberikan tugas untuk dikerjakan di rumah yang diambil dari buku paket, karena bel sudah berbunyi guru pun mengakhiri pertemuan dengan mengucapkan "Selamat siang:, dan siswa mengucapkan, "Selamat siang pak" dan guru pun keluar dari kelas.

\section{c) Observasi}

Untuk merekam aktivitas siswa dilakukan oleh dua pengamat sesuai dengan instruksi oleh peneliti.Pada pertemuan ketiga ini jumlah siswa yang masuk sebanyak 20 siswa (100\%). Aktivitas siswa pada pertemuan ketiga ini mengalami peningkatan dibandingkan dengan pertemuan 1 dan 2 (Siklus I). Siswa sudah agak aktif dalam mengungkapkan isi pikirannya pada saat diadakannya diskusi kelompok. Namun, ada sebagian siswa yang tidak aktif dan asik dengan kegiatannya sendiri, misalnya mengobrol dengan teman- temannya pada saat diskusi berlangsung, mengganggu teman yang sedang 
belajar. Hasil observasi pada pertemuan ketiga ini dapat dilihat pada tabel berikut ini:

Tabel 4.7. Aktivitas siswa pada pertemuan 3, siklus II.

\begin{tabular}{|l|l|c|c|c|}
\hline & \multicolumn{4}{|c|}{ Siklus II } \\
\hline No & Aktivitas & Jumlah & Skor & Persentase \\
\hline 1 & Menulis/membaca & 22 & 11 & $27.5 \%$ \\
\hline 2 & Mengerjakan & 33 & 16.5 & $41.25 \%$ \\
\hline 3 & $\begin{array}{l}\text { Bertanya pada } \\
\text { teman }\end{array}$ & 16 & 8 & $20 \%$ \\
\hline 4 & $\begin{array}{l}\text { Bertanya pada } \\
\text { guru }\end{array}$ & 6 & 3 & $7.5 \%$ \\
\hline & $\begin{array}{l}\text { Yang tidak } \\
\text { relevan dengan } \\
5\end{array}$ & 3 & 1.5 & $3.75 \%$ \\
\hline KUMMLAH & 40 & 40 & $100 \%$ \\
\hline
\end{tabular}

Pada tabel di atas dapat ditunjukkan bahwa aktivitas siswa yang lebih dominan adalah mengerjakan yaitu sebesar $41.25 \%$. Hal ini menunjukan bahwa siswa sudah mulai aktif mengerjakan tugas sesuai dengan indikator. Pada saat siswa berdiskusi, mereka sudah mulai berani mengemukan pendapat dan siswa yang tidak ikut serta dalam diskusi berkurang dilihat dari persentase jumlah yang tidak relevan dengan KBM yaitu $3.75 \%$.

\section{2) Pertemuan 4}

a) Pelaksanaan tindakan

KBM 4 dilakukan pada hari Rabu 25 Pebruari 2015 pada les 1 dan 2 kelas IX-A. Guru masuk ke kelas dengan menyapa siswa sambil senyum mengucapkan "Selamat pagi", siswa menjawab dengan nada bersemangat "pagi pak", lalu guru menyapa lagi dengan ucapan "apa kabar?", siswa menjawab sambil mengangkat tangannya "luar biasa".

Guru mengabsen siswa, ternyata siswa di kelas tersebut tidak ada yang absen, lalu guru membuka pelajaran dan memotivasi siswa agar lebih semangat lagi dalam mengikuti pembelajaran. Guru menyampaikan indikator pembelajaran dan memberikan pertanyaan seputar materi yang akan disampaikan kepada siswa. Setelah itu guru memberikan contoh soal tentang sumber daya alam di kawasan Asia Tenggara, penduduk di kawasan Asia Tenggara dan kegiatan ekonomi penduduk di kawasan Asia Tenggara, dan kerjasama Indonesia dengan negara-negara di kawasan Asia Tenggara.

Guru menyuruh siswa untuk membuat kelompok yang terdiri dari 4 orang perkelompok, dan guru memberikan soal kepada masingmasing kelompok untuk didiskusikan oleh kelompok tersebut, dan guru menentukan waktu diskusi sekitar 20 menit dengan memberikan soal sebanyak 4 soal.

Setelah 20 menit guru menyuruh satu orang untuk perwakilan satu kelompok supaya maju untuk mempresentasikan hasil diskusi tersebut, setelah seleai presentase guru mempersilahkan seluruh siswa perwakilan tersebut untuk duduk kembali, dan memnerikan penghargaan kepada siswa yang tampil dengan memberi nilai serta selanjutnya guru menerangkan/menjelaskan kembali untuk memperkuat dan memperjelas pengetahuan siswa, dengan memberikan beberapa contoh. Kemudian guru memberikan soal sebanyak 2 soal untuk dikerjakan siswa, setelah guru menilai/mencek jawaban yang dikerjakan setiap siswa ternyata sudah benar $90 \%$.

Karena waktu tinggal 10 menit lagi guru memberikan tugas untuk dikerjakan di rumah yang diambil dari buku paket, karena bel sudah berbunyi guru pun mengakhiri pertemuan dengan mengucapkan "Selamat pagi:, dan siswa mengucapkan, "Selamat pagi pak" dan guru pun keluar dari kelas. 
b) Observasi

Untuk merekam aktivitas siswa dilakukan oleh dua pengamat sesuai dengan instruksi oleh peneliti. Pada pertemuan keempat ini jumlah siswa yang masuk sebanyak 20 siswa (100\%). Aktivitas siswa pada pertemuan keempat ini mengalami peningkatan dibandingkan dengan pertemuan 3. Siswa sudah aktif dalam berpartisipasi pada saat diadakannya diskusi kelompok. Hal ini dapat dilihat dari persentase jumlah siswa yang tidak relevan dengan KBM yaitu $3.75 \%$.

\begin{tabular}{|c|c|c|c|c|}
\hline & \multicolumn{4}{|c|}{ Siklus II } \\
\hline No & Aktivitas & Jumlah & Skor & Proporsi \\
\hline 1 & Menulis/membaca & 23 & 11.5 & $57.5 \%$ \\
\hline 2 & Mengerjakan & 31 & 15.5 & $38.75 \%$ \\
\hline 3 & Bertanya pada teman & 16 & 8 & $20 \%$ \\
\hline 4 & Bertanya pada guru & 7 & 3.5 & $8.75 \%$ \\
\hline 5 & $\begin{array}{l}\text { Yang tidak relevan } \\
\text { dengan KBM }\end{array}$ & 3 & 1.5 & $3.75 \%$ \\
\hline & JUMLAH & 80 & 40 & $100 \%$ \\
\hline
\end{tabular}

dapat ditunjukkan bahwa siswa yang melakukan aktivitas yang tidak relevan dengan KBM masih tetap yaitu $3.75 \%$. Ini menunjukan bahwa siswa sudah tidak ada siswa yang main-main lagi, siswa sudah mulai bekerja yaitu $38.75 \%$.

Pada pertemuan 4 ini diadakan tes, tujuannya untuk mengetahui hasil belajar siswa dalam mempelajari IPS Terpadu dengan materi pokok Hubungan manusia dengan bumi

\section{Gambar 4.4.Grafik data hasil Formatif II}

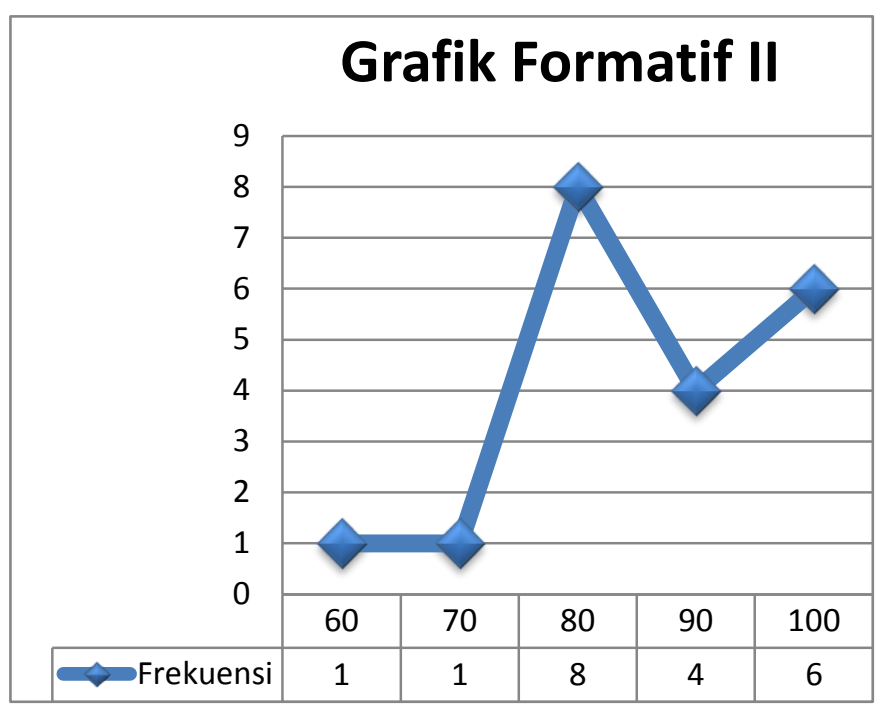

Setelah menganalisa data pada silkus II ini, langkah selanjutnya adalah mengamati perbandingan aktivitas siswa dan nilai rata-rata antara siklus I dengan siklus II.

\section{Grafik Aktivitas siklus II}

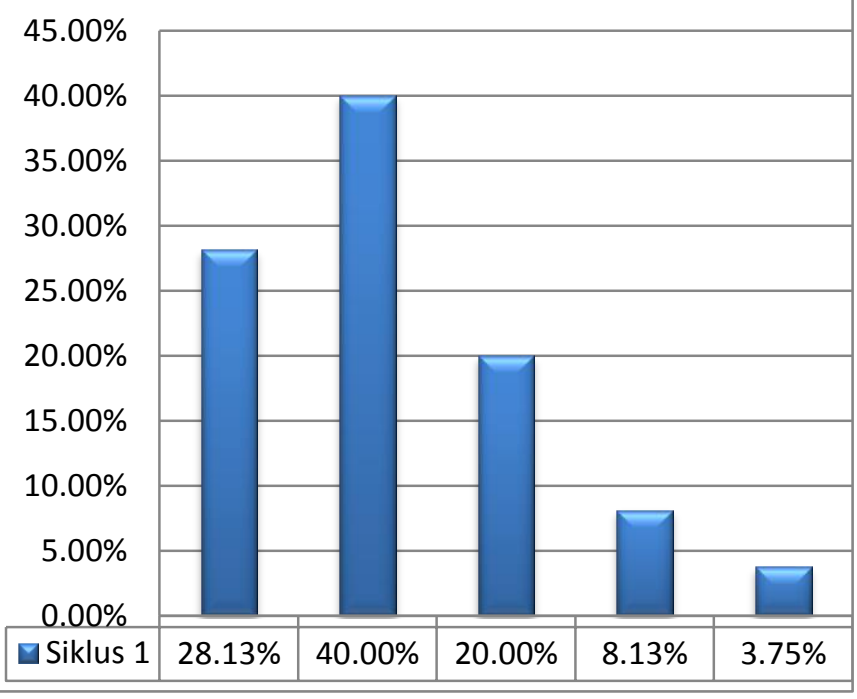

Gambar 4.5. Grafik aktivitas siswa Siklus I dan Siklus II 
Keterangan: 1. Menulis,membaca

2. Mengerjakan

3. Bertanya pada teman

4. Bertanya pada guru

5. Yang tidak relevan

Dari hasil pengamatan Siklus II selama dua pertemuan pembelajaran diperoleh data pengeololaan pembelajaran oleh guru. Pada saat pertemuan 3 dan 4 ini, guru telah melakukan perbaikan dari kelemahan yang ada pada siklus I.

\section{SIMPULAN DAN SARAN}

\section{Simpulan}

Data-data tes hasil belajar dan aktivitas belajar siswa terhadap model pembelajaran kooperatif Think Pair Share pada mata pelajaran IPS Terpadu dengan materi pokok Hubungan manusia dengan bumi di kelas IX-A SMP Negeri 1 Tambangan Tahun Pelajaran 2014/2015. Selama kegiatan belajar mengajar tersusun, kemudian dianalisis, sehingga dapat disimpulkan sesuai dengan rumusan masalah.

a. Data aktivitas siswa menurut pengamatan pengamat pada Siklus I adalah membaca/menulis (23.75\%), mengerjakan $(15.00 \%)$, bertanya pada teman $(20.63 \%)$, bertanya pada guru (21.25\%), dan yang tidak relevan dengan KBM (19.38\%). Sedangkan Data aktivitas siswa yang diperoleh pengamat pada Siklus II antara lain membaca/menulis (28.13\%), mengerjakan $(40.00 \%)$, bertanya pada teman $(20.00 \%)$, bertanya pada guru $(8.13 \%)$, dan yang tidak relevan dengan $\mathrm{KBM}$ (3.75\%).

b. Hasil belajar siswa pada mata pelajaran IPS Terpadu dengan materi pokok pokok Hubungan manusia dengan bumi di kelas IX-A SMP Negeri 1 Tambangan setelah mendapatkan pembelajaran dengan menerapkan model pembelajaran kooperatif Think-Pair-Share mengalami peningkatan pada akhir Siklus I dengan rata-rata 74.00 dan akhir Siklus II dengan rata-rata 86.50 dan ketuntasan klasikal $60 \%$ pada Siklus I menjadi $90 \%$ pada Siklus II sehingga mengalami peningkatan $30 \%$.

\section{Saran}

Dari hasil penelitian yang diperoleh dari uraian sebelumnya agar proses pembelajaran IPS Terpadu lebih efektif dan lebih memberikan hasil yang optimal bagi siswa, maka disampaikan saran sebagai berikut:

a. Agar didalam proses kegiatan belajar mengajar menggunakan model pembelajaran kooperatif Think-Pair-Share karena peneliti melihat antusias siswa didalam mengikuti proses pembelajaran.

b. Dalam rangka memperbaiki aktivitas belajar siswa, guru 


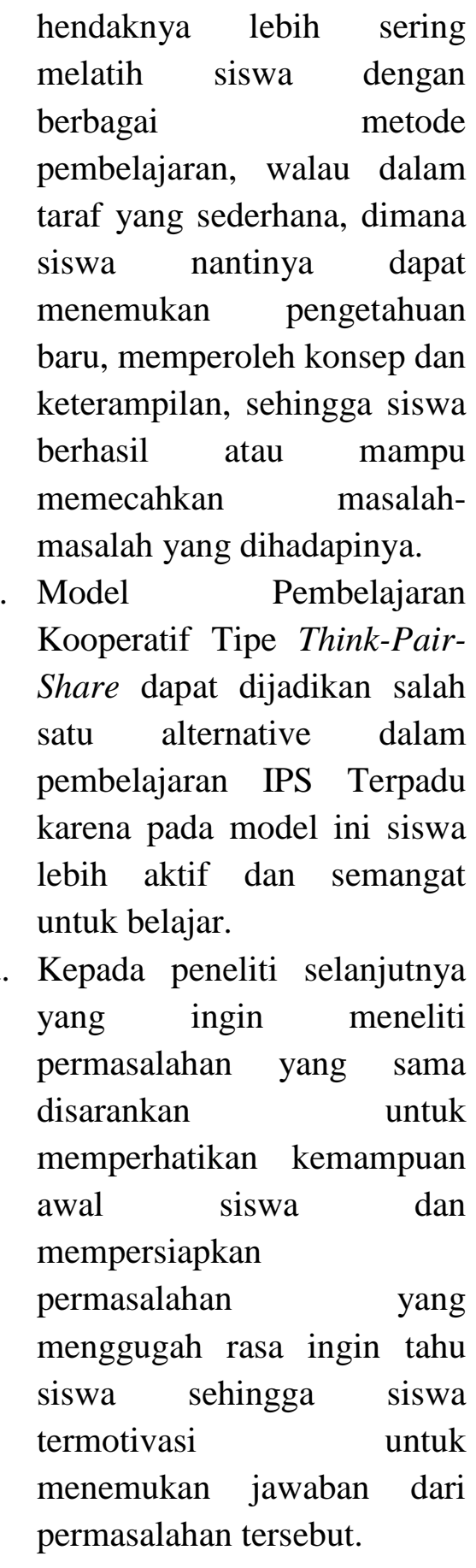

\section{DAFTAR RUJUKAN}

Aqib, Zainal. (2006). Penelitian

Tindakan Kelas. Bandung: Yrama Widya

Arends, R.I.(2009).Learning To Teach. Yogyakarta: Pustaka Belajar

Djamarah dan Aswin Zain. 2006. Strategi Belajar Mengajar. Jakarta : Rhineka Cipta

Odih Enjang, Sukadi. 1997. Ilmu pengetahuan sosial nasionala

Sagala, S.(2003). Konsep dan Makna Pembelajaran. Bandung: Alfabeta

Sardiman, S., dkk. 2010. Media Pendidikan. Jakarta : Rajawali Pers

Sirait, Baginda.1984.Ornamen Tradisional Daerah Sumatera Utara.Medan: CV Offset Bali

Slameto. 2003. Belajar dan FaktorFaktor yang Mempengaruhinya. Jakarta : Rineka Cipta

Sudjana, N. 2009. Penilaian Hasil Proses Belajar Mengajar. Bandung : PT Remaja Rosdakarya

Sukanti Dewi dkk. 2007. IPS terpadu untuk SMP kelas IX. Jakarta.

Sulistio Hasan dkk. 2007. IPS Terpadu untuk SMP Kelas IX Jakarta.

Suryadi dkk. 2008. Ilmu pengetahuan sosial untuk SMP/Mtas kelas IX. Solo. Penerbit Hamud. 